\title{
36. OXYGEN AND CARBON ISOTOPE RECORD THROUGH THE OLIGOCENE, DSDP SITE 366, EQUATORIAL ATLANTIC
}

\author{
Anne Boersma, Lamont-Doherty Geological Observatory of Columbia University, Palisades, New York \\ and \\ Nicholas Shackleton, Sub-Department of Quaternary Research, University of Cambridge, England, \\ and Lamont-Doherty Geological Observatory
}

\begin{abstract}
Detailed ${ }^{18} \mathrm{O}$ and ${ }^{13} \mathrm{C}$ records were constructed through the Oligocene section at Site 366 (DSDP Leg 41) in the eastern equatorial Atlantic. Samples were analyzed at intervals of more than one per million years using both benthic and planktonic foraminifera, and no significant hiatuses were encountered.

A survey of the depth habitats of planktonic foraminifera has shown that the chiloguembelinids, pseudohastigerinids, cassigerinellids, and in the latest Oligocene, Globigerinoides lived in the warmest waters. Below these surface forms the unkeeled globorotaliids, large globigerinids, small globigerinids occurred; Catapsydrax lived at the coolest temperatures.

The surface temperature at Site 366 ranges from $15^{\circ}$ to $16^{\circ}$ in the early Oligocene to $12^{\circ} \mathrm{C}$ in the late Oligocene. A significant temperature increase characterizes the termination of the Oligocene.

Intermediate depth temperatures are taken from the planktonic genus Catapsydrax whose temperature record closely parallels that of the benthonic foraminifera, suggesting that the deep water masses are controlled by high latitude processes independent of tropical surface conditions.

The ${ }^{13} \mathrm{C}$ variations demonstrate that the deep waters in the equatorial Atlantic were depleted in oxygen by about $2 \mathrm{ml} / \mathrm{l}$ compared with the South Atlantic Site 357.
\end{abstract}

\section{INTRODUCTION}

Stable isotope analyses were made on planktonic and benthonic foraminifera from Site 366 (Cores 5-8 and Cores 28A-39A) on Leg 41 in the eastern equatorial Atlantic. Holes 366 and $366 \mathrm{~A}$ were drilled at $04^{\circ} 40.70^{\prime} \mathrm{N}, 19^{\circ} 51.10^{\prime} \mathrm{W}$ at 2853 meters depth below sea level. The purpose of these analyses was to: (1) produce a temperature history of the equatorial Atlantic during the Oligocene which could be compared and contrasted with temperature histories at middle latitudes (Site 357) and high latitudes (Site 277); (2) to determine the timing and magnitude of major thermal changes during the Oligocene in the equatorial region; and (3) to compare the records of the Atlantic and Pacific tropical regions.

\section{ANALYTICAL PROCEDURE}

Our analytical methods for oxygen isotope analysis are described by Shackleton and Opdyke (1973). Samples were cleaned by ultrasonic vibration to remove adhering fine-grained particles, and purified by roasting in vacuo at $450^{\circ} \mathrm{C}$ for 30 minutes. Carbon dioxide for mass spectrometric analysis was relased by the action of $100 \%$ orthophosphoric acid at $50^{\circ} \mathrm{C}$ and transferred immediately to the mass spectrometer for isotopic analysis. Calibration to the PDB standard (Epstein et al., 1953) is probably accurate to better than 0.1 per mil, as shown by analyzing standard carbonates in the same way as foraminiferal samples (Shackleton, 1974). Analytical precision, judged by repeated sampling of standard carbonates, is about \pm 0.07 per mil; overall precision is generally found to be about \pm 0.11 per mil; additional uncertainty is the result of variability among the individual foraminifera analyzed (Shackleton and Opdyke, 1973). All data are presented in Table 1 (planktonics) and Table 2 (benthonics).

\section{ISOTOPIC COMPOSITION OF THE OCEAN}

We are only considering samples from the Oligocene and earliest Miocene in this investigation, that is to say earlier than the development of the East Antarctic ice sheet (Shackleton and Kennett, 1975). Shackleton and Kennett estimated the mean oxygen isotopic composition of the oceans prior to the formation of the ice sheet as -1.2 per mil relative to the PDB standard $(-1.0$ per mil to SMOW), that is 0.9 per mil lighter than today. Today, the deep water of the Atlantic is distinctly different isotopically from the remainder of the world ocean's deep waters (Epstein and Mayeda, 1953; Craig and Gordon, 1965), but there is, at present, no reason to suppose that it was so in the Paleogene. 
TABLE 1

Oxygen and Carbon Isotope Data for Planktonic Species

\begin{tabular}{|c|c|c|c|c|c|c|c|c|}
\hline \multirow{2}{*}{$\begin{array}{c}\text { Sample } \\
\text { (Interval in } \mathrm{cm} \text { ) }\end{array}$} & \multicolumn{2}{|c|}{ Catapsydrax sp. } & \multicolumn{2}{|c|}{$\begin{array}{c}\text { Globigerina } \\
\text { ampliapertura }\end{array}$} & \multicolumn{2}{|c|}{$\begin{array}{l}\text { Globorotalia } \\
\text { opima nana }\end{array}$} & \multicolumn{2}{|c|}{$\begin{array}{c}\text { Chiloguembelina } \\
\text { cubensis }\end{array}$} \\
\hline & ${ }_{\sigma}{ }^{18} 0$ & $\sigma^{13} \mathrm{C}$ & $\sigma^{18} 0$ & $\sigma 13 \mathrm{C}$ & ${ }_{\sigma}^{18} 0$ & ${ }^{13} \mathrm{C}$ & $\sigma^{18} 0$ & ${ }^{13} \mathrm{C}$ \\
\hline \multicolumn{9}{|l|}{ Hole $366 \mathrm{~A}$} \\
\hline $\begin{array}{l}28-6,40 \\
29-1,92 \\
29-6,77 \\
31-2,85 \\
33-1,137 \\
33-3,48 \\
38-1,24 \\
38-4,24^{a} \\
39-1,47\end{array}$ & $\begin{array}{l}+0.43 \\
+0.21 \\
+0.82 \\
+0.97 \\
+0.87 \\
+1.26 \\
-0.57 \\
+0.12 \\
+0.50\end{array}$ & $\begin{array}{l}+0.81 \\
-0.34 \\
+0.31 \\
+0.19 \\
+0.37 \\
+0.52 \\
+0.14 \\
+0.30 \\
+0.20\end{array}$ & & & $\begin{array}{l}-0.75 \\
-0.65 \\
-1.92 \\
-0.04 \\
+0.13\end{array}$ & $\begin{array}{l}+0.93 \\
+0.19 \\
+0.78 \\
+0.15 \\
+0.56\end{array}$ & -0.73 & +0.33 \\
\hline \multicolumn{9}{|l|}{ Hole 366} \\
\hline $\begin{array}{l}5-2,15 \\
5-4,116 \\
6-6,60 \\
7-4,87 \\
8-2,48 \\
8-4,23\end{array}$ & $\begin{array}{l}+1.02 \\
+0.54 \\
+1.06 \\
+0.32\end{array}$ & $\begin{array}{l}+0.42 \\
+0.36 \\
+0.53 \\
+0.54\end{array}$ & $\begin{array}{l}-0.16 \\
+0.11 \\
-0.87 \\
-0.44 \\
+0.03 \\
-0.42\end{array}$ & $\begin{array}{l}+0.37 \\
+0.76 \\
+0.60 \\
+0.75 \\
+0.84 \\
+0.59\end{array}$ & $\begin{array}{l}-0.81 \\
-0.07\end{array}$ & $\begin{array}{l}+0.97 \\
+0.03^{b}\end{array}$ & $\begin{array}{l}-1.33 \\
-1.23\end{array}$ & $\begin{array}{l}+0.81 \\
+0.85\end{array}$ \\
\hline $\begin{array}{l}\text { ane sample of } \\
\text { per mil and } \delta \\
\text { psydrax in the } \\
\text { value is not used }\end{array}$ & $\begin{array}{l}\text { Pseudoha } \\
{ }^{3} \mathrm{C}+0.14 \\
\text { same sam } \\
\text { in Figure }\end{array}$ & $\begin{array}{l}\text { stigerina, } \\
\text { per mil. } \\
\text { ple, we } \\
1 .\end{array}$ & pect & $\begin{array}{l}\text { A-38-4, } \\
\text { hese va } \\
\text { they }\end{array}$ & not & $\begin{array}{l}\text { zed and } \\
\text { ite clos } \\
\text { ect sur }\end{array}$ & $\begin{array}{l}\text { elded } \\
\text { o tho } \\
\text { cond }\end{array}$ & $\begin{array}{l}{ }^{18} 0-0.15 \\
\text { of Cata- } \\
\text { ions; the }\end{array}$ \\
\hline
\end{tabular}

TABLE 2

Oxygen and Carbon Isotope Data for Benthonic Species From Holes 366 and 366A

\begin{tabular}{|c|c|c|c|}
\hline $\begin{array}{c}\text { Sample } \\
\text { (Interval in } \mathrm{cm} \text { ) }\end{array}$ & & $\sigma^{18} 0$ & $\sigma^{13} \mathrm{C}$ \\
\hline \multicolumn{4}{|l|}{ Hole $366 \mathrm{~A}$} \\
\hline $\begin{array}{l}28-6-40 \\
29-1-92 \\
29-6-77 \\
30-1-85 \\
30-3-32 \\
31-2-85 \\
31-5-23 \\
33-1-137 \\
33-3-48 \\
34-6-71 \\
35-3-93 \\
36-1-40 \\
37-1-94 \\
38-1-24 \\
38-4-24 \\
39-1-47\end{array}$ & $\begin{array}{l}\text { Globocassidulina } \\
\text { mixed spp. } \\
\text { Globocassidulina } \\
\text { Globocassidulina } \\
\text { Globocassidulina } \\
\text { Globocassidulina } \\
\text { Globocassidulina } \\
\text { Globocassidulina } \\
\text { Globocassidulina } \\
\text { Globocassidulina } \\
\text { Globocassidulina } \\
\text { mixed spp. } \\
\text { Globocassidulina } \\
\text { mixed spp. } \\
\text { mixed spp. } \\
\text { mixed spp. }\end{array}$ & $\begin{array}{l}+1.91 \\
+1.44 \\
+1.82 \\
+1.78 \\
+1.74 \\
+1.76 \\
+1.63 \\
+1.84 \\
+2.27 \\
+1.67 \\
+1.82 \\
+1.64 \\
+1.60 \\
+1.57 \\
+1.06 \\
+1.45\end{array}$ & $\begin{array}{l}+0.31 \\
-0.57 \\
+0.16 \\
+0.19 \\
-0.32 \\
-0.18 \\
-0.08 \\
+0.10 \\
-0.09 \\
-0.26 \\
-0.69 \\
-0.18 \\
-0.17 \\
-0.16 \\
-0.03 \\
-0.16\end{array}$ \\
\hline \multicolumn{4}{|l|}{ Hole 366} \\
\hline $\begin{array}{l}5-2-15 \\
5-4-116 \\
6-2-143 \\
6-6-60 \\
7-2-13 \\
7-4-87 \\
8-2-48 \\
8-4-23\end{array}$ & $\begin{array}{l}\text { mixed spp. } \\
\text { mixed spp. } \\
\text { mixed spp. } \\
\text { mixed spp. } \\
\text { Uvigerina } \\
\text { mixed spp. } \\
\text { mixed spp. } \\
\text { mixed spp. }\end{array}$ & $\begin{array}{l}+1.34 \\
+1.80 \\
+1.43 \\
+1.48 \\
+1.68 \\
+1.70 \\
+1.75 \\
+1.30\end{array}$ & $\begin{array}{l}-0.55 \\
+0.17 \\
-0.14 \\
-0.44 \\
-0.51 \\
+0.07 \\
+0.15 \\
+0.04\end{array}$ \\
\hline \multicolumn{4}{|l|}{ Hole $366 \mathrm{~A}$} \\
\hline $\begin{array}{l}33-3-32 \\
33-3-48 \\
39-1-47 \\
\end{array}$ & $\begin{array}{l}\text { Cibicides } \\
\text { Cibicides } \\
\text { Cibicides }\end{array}$ & $\begin{array}{l}+1.79+2.19 \\
+1.84+2.24 \\
+1.31+1.71\end{array}$ & $\begin{array}{l}+0.93+0.03 \\
+0.91+0.01 \\
+0.07-0.83 \\
\end{array}$ \\
\hline
\end{tabular}

Therefore we can estimate deep water temperatures by using the value for the average oceans given above.

In the modern ocean, low latitude surface waters are generally higher in salinity, and isotopically heavier, than deep water (Craig and Gordon, 1965). For example, the Atlantic has values in the region of +1.0 per mil. Although Craig and Gordon argue that the same trend is likely to have prevailed over very long periods, Boersma and Shackleton (in preparation) show that the isotopic gradient between low and high latitudes in the Paleogene is likely to have been less than today. In Figure 1 we have estimated surface temperatures without taking this factor into account; however, this may cause us to underestimate surface temperatures by a degree or two.

\section{MEASUREMENTS AND CALIBRATIONS OF FORAMINIFERA}

At least one benthonic and several planktonic foraminiferal species were analyzed in most samples. To avoid the problems of isotopic differences between adults and juveniles, between different genera, and between summer and winter populations, only adult specimens of each species were analyzed. More than nine planktonic specimens were picked to average the summer and winter variations and calibrated benthonic foraminifera (Shackleton, 1974; Shackleton, Boersma, and Streeter, in preparation) were used in the analyses when possible. When it was necessary to use a mixed benthonic sample, species known to deviate from equilibrium were avoided.

Reconstruction of a surface temperature requires selection of surface-dwelling planktonic foraminifera. 


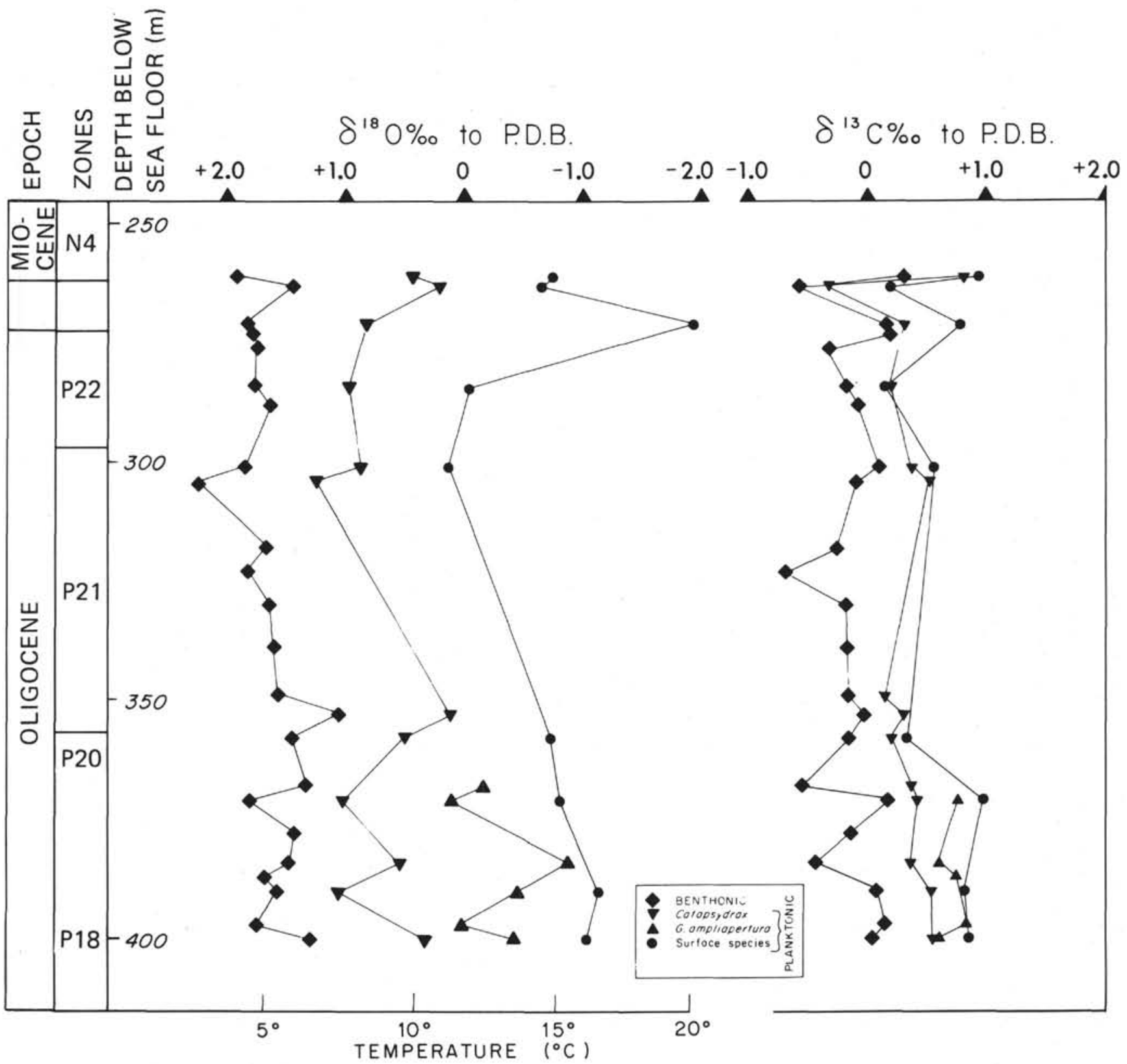

Figure 1. Oxygen and carbon isotope measurements for the Oligocene section of Site 366. Foraminiferal zones (Krasheninnikov, this volume) after Blow (1969) and Berggren (1972). Left part of figure is oxygen isotopic measurements for planktonic and benthonic species, with temperature scale below. Right part of figure is carbon isotopic measurements for planktonic and benthonic species. Data from Tables 1 and 2.

Today Globigerinoides is known to dwell in the surface waters (Bé and Tolderlund, 1971). Although Globigerinoides evolved in the later Oligocene, it is not abundant enough at this site to be used for analysis. Oligocene faunas are generally dominated by large globigerinids, with Catapsydrax and globorotaliids secondary in importance, so that samples of mixed planktonic species would probably incorporate a proportionately large number of globigerinids. In order to establish which species would be most likely to reveal surface temperature, suites of species were analyzed from different localities, particularly from both lower and middle latitudes, in order to establish the stratification order and the vertical (temperature) spread among the various species. Experience from the Eocene (Boersma and Shackleton, 1977) and from the Recent (Vincent and Shackleton, 1975) shows that the vertical spread of species in the water column changes from cooler to warmer regions and that under warmer surface waters there are greater vertical (temperature) differences between the shallowest and the deepest dwelling species. The results of a few analyses of selected planktonic species are shown in Figure 2. In these and other analyses Chiloguembelina, Cassigerinella, Pseudohastigerina, and the unkeeled globorotaliids consistently record the warmest temperatures; the globigerinids occupy intermediate ranges; and Catapsydrax produces the lowest tempera- 


\section{$28^{\circ} \mathrm{S}$}

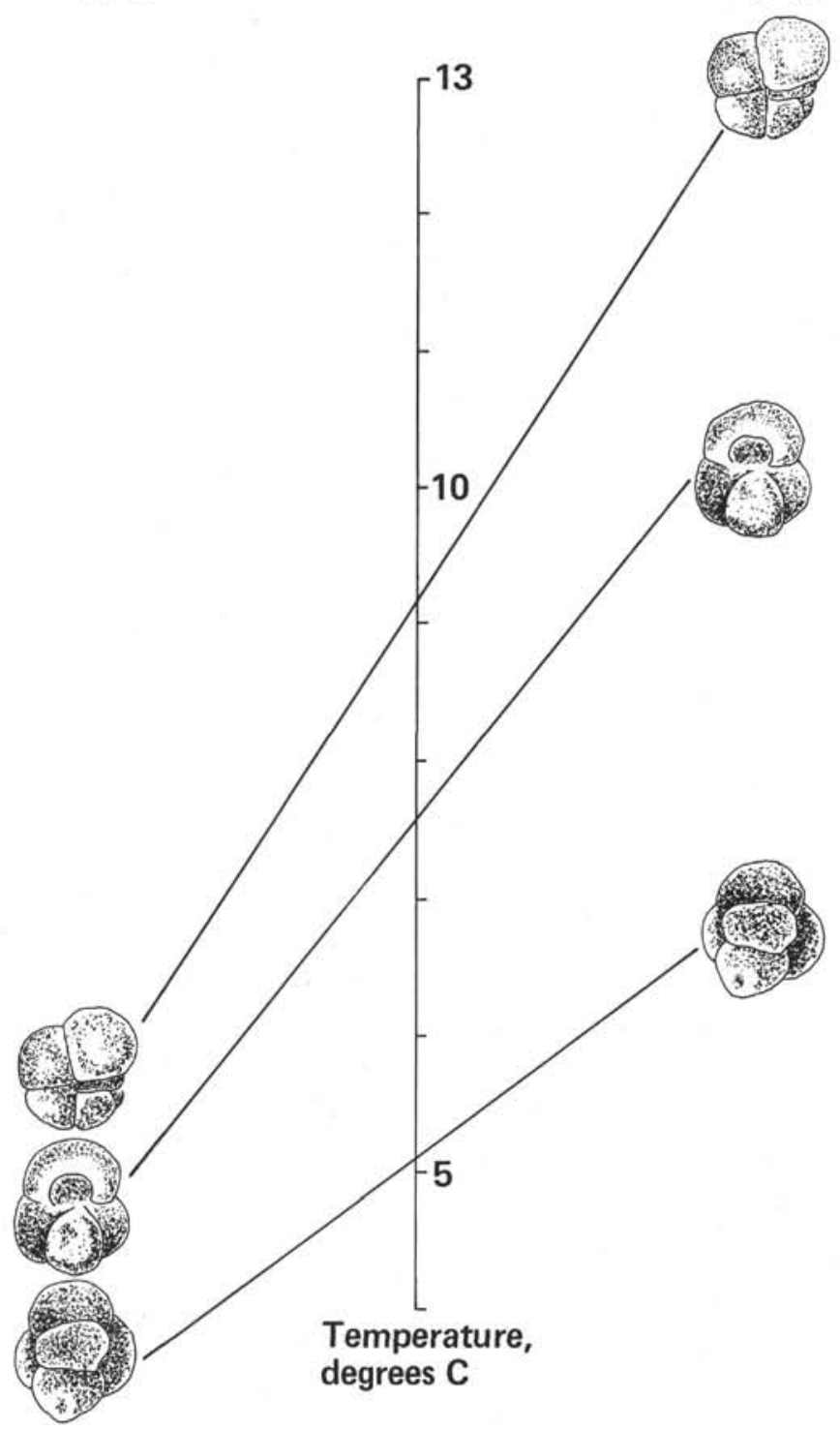

Figure 2. Temperatures (determined by isotopic means) occupied by three planktonic foraminifera during Oligocene Zone P19. Shallowest is Globorotalia opima nana; intermediate is Globigerina ampliapertura; deepest is Catapsydrax sp. To the left, from DSDP Site 17 (midlatitude South Atlantic), and to the right from DSDP Site 366 (equatorial Atlantic).

tures. Because not all species of the globigerinids were analyzed, there may be some deeper dwelling species as in the Eocene; however, the Globigerina praebulloides, $G$. ampliapertura, G. tapuriensis, and $G$. ouachitaensis groups have been analyzed, and none produced results comparable with those of the surface forms.

Because of the results of the above analyses, Chiloguembelina cubensis and Globorotalia opima nana were used for the construction of the surface temperature curve. We emphasize that not all Oligocene species have been analyzed and, in particular, the tiny smooth globorotaliid-form species in the fine fraction may yet prove to register even higher temperatures than Chiloguembelina or Cassigerinella.
The vertical range of temperatures at middle latitudes from the shallowest (Chiloguembelina) to the deepest form (Catapsydrax) is $3^{\circ} \mathrm{C}$. The spread between species becomes greater closer to the equatorial zone (between Globorotalia opima nana and Catapsydrax it may exceed $6^{\circ} \mathrm{C}$ ).

We conclude that even in the Oligocene when temperatures were generally low and foraminiferal depth stratification was likely to be more compact, there is a marked temperature range between the shallow and the deep-dwelling species, and that this difference increases significantly during warmer periods and from intermediate to low latitudes.

\section{SEDIMENTS AND FAUNAS FROM SITE 366}

Holes 366 and $366 \mathrm{~A}$ were drilled on the crest of the Sierra Leone Rise. The two Oligocene sections analyzed for this report consist of greenish gray nanno ooze and chalk, and dark greenish gray marl and clay. Both sections are intensely burrowed and there is slight drilling disturbance in the youngest few cores (Site Report 366, this volume). Preservation and induration of the sediments vary markedly from sample to sample. These sections display cyclical deposition with an average of 15 to $40 \mathrm{~cm}$ per cycle (Dean et al., this volume). These cycles were not sampled in detail in this study because of induration problems.

The lithologies of the samples are either chalk containing pyrite and a few Radiolaria (Sections 39-1, $38-1,36-2)$, or less chalky with no pyrite and abundant Radiolaria (Samples 38-4, 37-1, 29-1).

Foraminiferal residues contain tropical planktonic foraminifera throughout. However, preservation of these faunas varied markedly, resulting in unusual species abundances in some samples. Reworking and contamination did not present the problems at this site as occurred in samples from Site 357 (Boersma and Shackleton, 1977).

Benthonic foraminifera are never very abundant in these residues, and several analyses are, by necessity, based on samples of mixed benthonics species.

\section{BOTTOM TEMPERATURES}

We were unable to analyze single species of benthonic foraminifera in the lower Oligocene section covered in Hole 366; however, the mixed species used did not include those known to deviate significantly from isotopic equilibrium. We were able to analyze Globocassidulina in most samples from Hole 366A and Cibicides in a few. Cibicides deviates by about -0.4 per mil from isotopic equilibrium (Shackleton, Boersma, and Streeter, in preparation). The values plotted in Figure 1 are adjusted by this amount. In the sample yielding the lowest bottom temperature, we analyzed both Globocassidulina and two large specimens of Cibicides. The concordance between the three analyses is the best criterion presently available for assessing the accuracy of an oxygen isotope paleotemperature estimation.

With the exception of Section 366A-33-3, values for Globocassidulina are tightly bunched between +1.60 and +1.91 , an overall range corresponding to scarcely more than about $4^{\circ}$ to $5^{\circ} \mathrm{C}$. This result is similar to the 
values obtained in the shallower Site 357 (Boersma and Shackleton, 1977) which are also well-calibrated analyses. The measured isotopic range is greater among the samples from which a mixture of species were analyzed; Section 366A-38-4 yielded +1.04 per mil. This value is lighter isotopically (i.e., warmer) than any calibrated analysis from Site 357 and we would regard it as a dubious value, except that the values for Catapsydrax also indicate a deep-water warming in this sample.

On the basis of analyses in the relatively shallow Site 277, Shackleton and Kennett (1975) argued that the thermal structure of the oceans during the Oligocene was similar to that today. However, we now see, at least for the deep Atlantic, this was not so. Site 366 yields temperatures that were slightly warmer than today. Unfortunately, there are few values available from the deep Pacific Ocean, but those given by Douglas and Savin (1973) correspond to a temperature range of $2^{\circ}$ to $4^{\circ} \mathrm{C}$, using the ocean isotopic composition value of -1.2 per mil. Thus, it appears that there may have been a significant temperature difference between the deep waters of the equatorial regions of the Atlantic and Pacific at this time. Evidently, relatively cold water that entered the Pacific was not able to penetrate into the Atlantic. This is consistent with circulation patterns in the Oligocene of the South Atlantic inferred by McCoy and Zimmerman (1977).

\section{SURFACE TEMPERATURES}

The derivation of surface temperatures from oxygen isotope determinations is complicated both by possible salinity-related isotopic variations in surface waters, and by the unknown depth habitats of extinct foraminiferal groups. As discussed above, the first problem may be less serious than might be supposed on the basis of data for the modern ocean. We have selected for surface temperature estimates planktonic species that we have shown to be stratified nearest the surface (out of those analyzed); Globorotalia opima nana, Pseudohastigerina barbadoensis, and Chiloguembelina cubensis. Probably the most striking aspect of our results is the wide range in temperature recorded. Absolute temperature values are about $15^{\circ}$ to $16^{\circ} \mathrm{C}$ in the early Oligocene and about $12^{\circ} \mathrm{C}$ in the late Oligocene, with a dramatic rise to about $20^{\circ} \mathrm{C}$ just below the base of the Miocene. The highest value is near $20^{\circ} \mathrm{C}$ in Section 366A-29-6, and the lowest about $12^{\circ} \mathrm{C}$ in Section 366A-33-1. This suggests that at low latitudes the thermal history of the Oligocene may have been considerably more complex than has previously been documented. The extent of this complexity can only be appreciated by more detailed sampling than has been undertaken for this report.

\section{INTERMEDIATE DEPTH TEMPERATURES}

We analyzed in a number of samples the presumed deep dwelling species Catapsydrax sp. As is seen from Figure 1, both the oxygen and carbon isotope analyses support the notion that this genus inhabited deeper water (although we are unable to estimate the actual depth). It is interesting to note, however, that the trends of temperature change in benthonic species and in Catapsydrax are very similar, whereas the trends for surface species are quite independent. This might suggest that Catapsydrax lived below the thermocline, and (as one might expect) that the temperature of the whole deep-water mass was controlled by high latitude processes only loosely coupled to tropical surface conditions.

We also analyzed Globigerina ampliapertura from the lower part of the section. The rather erratic changes recorded in this species suggest that it lived within the thermocline. Because small depth changes within the thermocline would involve significant temperature changes, it is unlikely that further isotope analyses of this species would give much paleoenvironmental information at present.

\section{DEEP WATER CARBON ISOTOPE DATA}

Using data from Site 366 we are able for the first time to demonstrate a clear pattern of deep water ${ }^{13} \mathrm{C}$ variations. This is possible because we have analyzed both benthonic foraminifera, which are postulated to reflect changes in ${ }^{13} \mathrm{C}$ content at the sediment-water interface, and deep living planktonic species (Catapsydrax) which might be expected to live below the oxygen minimum zone and below the region of steep vertical ${ }^{13} \mathrm{C}$ gradients (Kroopnick, 1974).

The ${ }^{13} \mathrm{C}$ content at the sea floor might differ from that of the bulk of oceanic deep water because of oxidation of organic matter at the interface. Thus, there is no certainty that benthonic Foraminifera reflect only changes in ocean ${ }^{13} \mathrm{C}$ content (Shackleton, 1976). However, we cannot be certain that the habitat of Catapsydrax is as postulated above. In Figure 1 the ${ }^{13} \mathrm{C}$ content of the two groups may be compared. It is seen that the mean ${ }^{13} \mathrm{C}$ difference is about 0.4 per mil and the two are fairly well correlated. We conclude that the major mechanism for these variations is a change in ${ }^{13} \mathrm{C}$ content of $\mathrm{CO}_{2}$ dissolved in deep water, which would affect both Catapsydrax and benthonic species.

Both the Catapsydrax values and the benthonic values (for Globocassidulina) can be compared with Site 357 on the Rio Grande Rise (Boersma and Shackleton, 1977). These values from Site 366 samples are isotopically lighter, by about 0.5 and 0.4 per mil, respectively than those from Site 357 . If we assume that the processes involved were similar to those documented by Kroopnick et al. (in press) in today's ocean, then this would imply that deep water in the equatorial Atlantic was depleted in oxygen by about $2 \mathrm{ml} / 1$ compared with the South Atlantic. At present insufficient data exist to reconstruct circulation patterns from these data; the carbon isotopic disequilibrium effects are so great that such comparisons can only be made reliably on the basis of monospecific samples. However, the fact that the South Atlantic to equatorial Atlantic difference was registered both by the benthonic species and by the deep-dwelling planktonics strongly suggests that this is a true deep water carbon isotopic gradient. 


\section{SURFACE WATER CARBON ISOTOPE DATA}

Among several, but not all planktonic species, the carbon isotope stratification appears to resemble that observed in the water column (Vincent and Shackleton, 1975). Species living near the surface yield the most positive ${ }^{13} \mathrm{C}$ values. This is also generally true for Paleogene species (Boersma and Shackleton, in preparation). However, it is by no means certain that the shallowest foraminiferal species actually reflects the ${ }^{13} \mathrm{C}$ content of surface water, so that it is unclear to what extent Broecker's (1971) suggestion that the surface-to-bottom carbon isotope gradient monitors productivity, can be usefully pursued. In this respect, an important result of the study of Margolis et al. (1975) is that in the Oligocene, when foraminifera from Site 277 and elsewhere indicate less positive ${ }^{13} \mathrm{C}$ values than in the Eocene or Miocene, the coccoliths show no such effect. Because coccoliths are known to be photic, their values are more likely to be correct, which suggests that foraminifera in the Oligocene do not reflect surface ${ }^{13} \mathrm{C}$ content. Thus we do not attempt to derive surface-water carbon isotopic changes.

\section{CONCLUSIONS}

Fluctuations occurred in surface water temperatures in the equatorial Atlantic during the Oligocene. We record a maximum temperature of about $20^{\circ} \mathrm{C}$ at the end of the Oligocene, and a minimum temperature of about $12^{\circ} \mathrm{C}$ near the P21-P22 foraminiferal zone boundary. Partly independent fluctuations occurred in deep and bottom water temperatures. Temperature maxima occurred at the base of the sequence early in Zone P18, near the base of Zone P21, and very early in the Miocene but they do not coincide with surface temperature maxima.

Carbon isotope values (both for benthonic foraminifera and deep dwelling planktonic foraminifera) show that deep water at this locality was considerably "older" (i.e., depleted in oxygen and enriched in $\left.\Sigma \mathrm{CO}_{2}\right)$ than was deep water in the South Atlantic.

\section{ACKNOWLEDGMENTS}

The authors would like to thank Yves Lancelot for providing the opportunity to work on these samples. The DSDP staff at Lamont-Doherty were exceptionally helpful in providing samples. This work is supported by NSF Grant OCE74-24110 to A.B., and by N.E.R.C. Grant GR3/1762 to N.J.S. The V.G. Micromass mass spectrometer on which the isotopic analyses were made was operated with consistent care by M.A. Hall.

\section{REFERENCES}

Bé, A.W.H. and Tolderlund, D.S., 1971. Distribution and ecology of living planktonic foraminifera in surface waters of the Atlantic and Indian oceans. In Funnell, B.M., and Riedel, W.R. (Eds.), The micropalaeontology of oceans: Cambridge (Cambridge University Press), p. 105-149.

Berggren, W.A., 1972. A Cenozoic time-scale-some implications for regional geology and paleobiogeography: Lethaia, v. 5, p. 195-215.

Blow, W.H., 1969. Late Eocene to Recent planktonic foraminiferal biostratigraphy. First Internat. Conf.
Plankt. Microfossils (Geneva, 1967), Proc., v. 1, p. 199422.

Boersma, A. and Shackleton, N., 1977. Tertiary oxygen and carbon isotopic stratigraphy: Site 357 (mid latitude South Atlantic). In Perch-Nielsen, K., Supko, P.R., et al., Initial Reports of the Deep Sea Drilling Project, Volume 39: Washington (U.S. Government Printing Office), p.

Broecker, W.S., 1971. A kinetic model for the chemical composition of sea water. Quat. Res., v. 1, p. 188-207.

Craig, H. and Gordon, L.I., 1965. Deuterium and oxygen 18 variations in the ocean and the marine atmosphere: Consiglio Nazionale Delle Ricerche, Pisa, 1965.

Douglas, R.G. and Savin, S.M., 1973. Oxygen and carbon isotope analyses of Cretaceous and Tertiary foraminifera from the central North Pacific. In Winterer, E.L., Ewing, J.I., et al., Initial Reports of the Deep Sea Drilling Project, Volume 17: Washington (U.S. Government Printing Office), p. 591-605.

Epstein, S. and Mayeda, T. 1953. Variation of $\mathrm{O}^{18}$ content of waters from natural sources: Geochim. Cosmochim. Acta, v. 4 , p. 213-224.

Epstein, S., Buchsbaum, R., Lowenstam, H.A., and Urey, H.C., 1953. Revised carbonate-water isotopic temperature scale: Geol. Soc. Am. Bull., v. 64, p. 1315-1326.

Kroopnick, $\mathrm{P} ., 1974$. The dissolved $\mathrm{O}_{2}-\mathrm{CO}_{2}-{ }^{13} \mathrm{C}$ system in the eastern equatorial Pacific: Deep-Sea Res., v. 21, p. 211227.

Kroopnick, P.M., Margolis, S.V., and Wong, C.S., in press. $\delta^{13} \mathrm{C}$ variations in marine carbonate sediments as indicators of the $\mathrm{CO}_{2}$ balance between the atmosphere and the oceans: O.N.R.: The fate of Fossil Fuel $\mathrm{CO}_{2}$ in the oceans.

McCoy, F. and Zimmerman, H., 1977. A history of sediment lithofacies in the South Atlantic Ocean. In Perch-Nielsen, K., Supko, P.R., et al., Initial Reports of the Deep Sea Drilling Project, Volume 39: Washington (U.S. Government Printing Office), p.

Margolis, S.V., Kroopnick, P.M., Goodney, D.E., Dudley, W.C., and Mahoney, M.E., 1975. Oxygen and carbon isotopes from calcareous nannofossils as paleooceanographic indicators: Science, v. 189, p. 555-557.

Shackleton, N.J., 1974. Attainment of isotopic equilibrium between ocean water and the benthonic foraminifera genus Uvigerina: isotopic changes in the ocean during the last glacial: Coll. Internat. Centre National de la Recherche Sci., v. 219, p. 203-210.

Shackleton, N.J., 1976. Carbon-13 in Uvigerina: tropical rainforest history and the Equatorial Pacific carbonate dissolution cycles. In Andersen, N.R., and Malahoff, A. (Eds.), The fate of fossil fuel $\mathrm{CO}_{2}$ in the oceans:

Shackleton, N.J. and Kennett, J.P., 1975. Paleotemperature history of the Cenozoic and the initiation of Antarctic glaciation: oxygen and carbon isotope analyses in DSDP Sites 277, 279, and 281. In Kennett, J.P., Houtz, R.E., et al., Initial Reports of the Deep Sea Drilling Project, Volume 29: Washington (U.S. Government Printing Office), p. 743-756.

Shackleton, N.J. and Opdyke, N.D., 1973. Oxygen isotope and palaeomagnetic stratigraphy of Equatorial Pacific core V28-238: oxygen isotope temperatures and ice volumes on a $10^{5}$ year and a $10^{6}$ year scale: Quat. Res., v. 3 , p. $39-55$.

Vincent, E. and Shackleton, N.J., 1975. Oxygen and carbon isotope composition of Recent planktonic foraminifera from the southwest Indian Ocean: Geol. Soc. Am. Annual Mtg., v. 7, p. 1308. 